\title{
Deiksis dalam Bahasa Tontembuan
}

\author{
Louisa Rina Moningka \\ Fakultas Ilmu Budaya \\ Universitas Sam Ratulangi
}

\begin{abstract}
Research on Tontemboan deixis is focused on describing the form and function of deixis. This type of research is qualitative by using descriptive methods, especially in collecting data, describing data scientifically, and producing linguistic rules in a linguistic manner. Most of the data used for analysis needs are taken from the field through informants and data from the library is taken from books and available research results that are used to complement the data. Data collection techniques used direct observation techniques, tapping records, notes, and interviews. For data analysis, the inductive method was used to obtain results which indicated that in terms of deixis forms could be morphemes, words and phrases. The form of morpheme is found in the possessive form. The form of a phrase appears on the deixis which states the past time (kawi? makasa 'day before yesterday') and the future time (wo? ndo ang kadouan 'the day after tomorrow', ang kateluan ngando 'two days after tomorrow', the speed of ngando 'three days after tomorrow'). Some forms of deixis have free variations, such as the time markers for the coming time for the word ngando mei 'two days after tomorrow' and the time for ngando mei / epat ngando mei 'three days after tomorrow' and the personal markers for the third pronent sera / sela / seila 'they', which the shapes are interchangeable. Unless the form of sera / sela / seila 'they' is indicated by speakers who are in the area of the makela? I use the word seila 'they'. In terms of function, deixis has a function according to the type of deixis. In the Tontemboan language there is only one form of deixis which refers to him being male and her being female. Deixis which shows the place or space there are 3 deixis, namely ambi? 'here', am bitu 'there' and asyianonge 'there'. The Tontemboan language recognizes an exclusive form of cami 'we' and an inclusive form of 'our'. Starting from Frei's hypothesis, the cultural link with the Tontemboan language deixis can provide an overview of the extent of the existing cultural levels.
\end{abstract}

Keywords : deixis, language, Tontemboan

\section{Pendahuluan}

Bahasa sebagai alat berinteraksi manusia antara satu dan yang lainnya sehingga saling memahami apa yang dibicarakan atau apa yang dimaksud. Tiap kelompok atau daerah memiliki bahasa sendiri yang disebut bahasa daerah. Bahasa Tontemboan adalah salah satu bahasa daerah / dialek di Minahasa, Propinsi Sulawesi Utara, yang digunakan oleh penduduk yang bermukim di wilayah-wilayah seperti, antara lain di Tareran, Kawangkoan, Langoan, Tumpaan, Motoling, Amurang, Sonder dan lain-lain. Sebagai pendukung kebudayaan Minahasa, bahasa Tontemboan disinyalir semakin menurun penggunaannya disebabkan para penuturnya sudah berusia lanjut, para generasi muda kurang berminat menggunakan bahasa daerah mereka, karena mungkin saja menganggap ketinggalan jaman ketika berbahasa daerah, merasa malu atau berperasaan rendah, ditambah lagi dengan kehadiran produk-produk teknologi yang berbahasa asing yang digemari oleh generasi muda, bahkan belum ada kesadaran dari orang tua untuk berkomunikasi bahasa daerah terhadap anak-anak ketika berada di rumah. Hal-hal seperti inilah yang lebih mempercepat punahnya bahasa daerah. Untuk mengatasi permasalahan ini, maka harus dicari jalan keluar 
untuk menghindari kepunahan, yaitu dengan melakukan penelitian secara berkesinambungan sehingga menghasilkan suatu rumusan yang berupa formula yang kemudian didokumentasikan dan nantinya dapat menjadi pegangan/acuan bagi pengajar bahasa daerah di sekolah-sekolah ketika pemerintah daerah benar-benar ingin melindungi salah satu kekayaan daerah yaitu bahasa daerah dengan memasukkan dalam kurikulum pendidikan sebagai muatan lokal.

Dalam hubungan dengan budaya, dapat saja hal-hal menyangkut kebiasaan atau normanorma, dan lain-lain tercermin dalam bahasa daerah. Dalam bahasa Tontemboan, kajian mengenai deiksis belum pernah dilakukan, bahkan orang menganggap bahwa sangat sukar mempelajari deiksis bagi orang yang tidak menguasai bahasa yang diteliti. Oleh karena itu, peneliti tertarik untuk mengetahui deiksis bahasa Tontemboan, yang difokuskan pada permasalahan mengenai bentuk dan fungsi deiksis. Penelitian ini dilakukan untuk memperoleh deskripsi tentang bentuk deiksis yang ada dalam bahasa Tontemboan, dan juga bagaimana fungsinya, serta penggunaannya. Adakah cerminan budaya yang nampak pada deiksis bahasa Tontemboan.

\section{Metode Penelitian}

Penelitian ini adalah penelitian kualitatif yang lebih menekankan kualitas (ciri-ciri data alamiah). Metode deskriptif juga digunakan untuk memberi gambaran/deskripsi mengenai bentuk-bentuk dan fungsi-fungsi deiksis dalam bahasa Tontemboan, yang beupa kata-kata (Djajasudarma, 1993). Perolehan data dilakukan melalui studi lapangan, dengan memanfaatkan informan-informan penutur bahasa Tontemboan yang berada di wilayah makela? $i$ dan matana? . Data-data dari lapangan kemudian di diskusikan dengan penutur yang dianggap paham benar (konsultan) tentang bahasa Tontemboan. Sumber data lain melalui pustaka, yaitu berupa hasil penelitian, kamus, dan jurnal untuk melengkapi data lapangan. Tempat pengumpulan data meliputi desa Taraitak dan desa Kiawa yang ada di Kabupaten Minahasa. Proses penelitian dengan melakukan studi pustaka, kemudian turun lapangan atau perpustakaan untuk mengumpulkan data dengan teknik sadap rekam, teknik catat, dan wawancara dengan rekaman atau catatan Sudaryanto (dalam Purwo, 1984). Setelah data terkumpul, yang berupa korpus diolah dan dianalisis. Untuk menganalisis atau mengkaji data ditempuh cara induktif, yakni data dikaji melalui proses yang berlangsung dari fakta (data) ke teori (Djajasudarma, 1993). dengan metode kajian berdasarkan teori-teori yang telah ditetapkan. Hasil yang diperoleh kemudian disusun menjadi sebuah laporan penelitian.

\section{Landasan Teori}

Kajian kebahasaan yang berkaitan dengan penelitian ini telah dilakukan oleh Purwo (1984) tentang deiksis bahasa Indonesia. Beliau melakukan kajian deiksis dengan menyoroti aspek sintaktis dan aspek semantis leksikalnya. Dalam bahasa Tontemboan sejauh peninjauan peneliti belum pernah dilakukan penelitian tentang deiksis. Namun kajian selain deiksis sudah banyak dilakukan, diantaranya menyangkut Kamus, Struktur, Morfologi, dan Sapaan.. Kajian tentang deiksis dalam bahasa Tombulu telah dilakukan oleh Moningka dan Tim (2019) dengan membandingkan deiksis bahasa Jerman. Penelitian ini hanya terbatas pada perolehan bentukbentuk deiksis dan fungsinya. Untuk menganalisis deiksis bahasa Tontemboan ini ditempuh cara dengan memanfaatkan pendapat beberapa ahli seperti pendapat Purwo (1984) tentang konsep deiksis. Dikatakannya bahwa sebuah kata bersifat deiktis apabila referennya berpindah- pindah atau berganti-ganti tergantung pada siapa yang menjadi pembicara dan pada saat dan tempat dituturkannya kata itu.

Bagi Lyons (1977) konsep deiksis digunakan untuk menggambarkan fungsi 1) pronomina persona; 2) demonstrativa; 3) fungsi waktu; 4) aneka ciri gramatikal; serta 5) leksikal lainnya. Referen nanti diketahui jika diketahui pula siapa penutur, di tempat mana dilangsungkan tuturan, dan pada waktu kapan tuturan diucapkan. Yule membagi deiksis atas 3 jenis, yaitu deiksis persona, deiksis tempat, dan deiksis waktu. Masing- masing deiksis memiliki fungsinya masing- 
masing sesuai dengan jenis deiksisnya. Untuk mengetahui bentuk deiksis dan fungsinya, maka Sumarsono (dalam Putrayasa, 2014) berpendapat bahwa bentuk deiksis biasanya dihubungkan dengan jumlah kata pendukungnya. Berdasarkan hal tersebut, bentuk deiksis digolongkan menjadi tiga, yaitu deiksis yang berupa morfem, deiksis berupa kata, dan deiksis yang berupa frasa. Kaitan budaya dengan deiksis, maka bahasa Tontemboan dapat memberi gambaran sejauhmana tingkat kebudayaan yang ada. Sebagaimana hipotesis Frei yang mengatakan bahwa semakin tinggi tingkat kebudayaan, maka seharusnya semakin sederhana sistem deiktis bahasa bersangkutan, dalam arti bahasa tersebut tidak memerlukan deiksis yang banyak dan rumit.

\section{Hasil Dan Pembahasan}

Penelitian yang dilakukan ini lebih difokuskan pada bentuk dan fungsi deiksis persona, deiksis ruang/tempat, dan deiksis waktu. Data yang jadikan sebagai bahan analisis diperoleh dari informan-informan yang bermukim di daerah Matana'i dan daerah Makela'i, dan juga dari penelitian-penelitian yang berhubungan dengan bahasa Tontemboan.

\section{Deiksis Persona}

\begin{tabular}{|c|c|c|c|}
\hline Persona & Deiksis & Bentuk & Fungsi Deiksis \\
\hline \begin{tabular}{|l} 
A. $\quad$-Persona \\
Pertama Tunggal
\end{tabular} & $\begin{array}{l}\text { yaku (saya) } \\
-\mathbf{k u}(-\mathrm{ku})\end{array}$ & $\begin{array}{l}\text { bentuk bebas } \\
\text { bentuk terikat /lekat } \\
\text { kanan }\end{array}$ & $\begin{array}{l}\text {-menunjuk pada pembicara sendiri } \\
\mathrm{t} \text {-menyatakan milik pembicara }\end{array}$ \\
\hline \begin{tabular}{|l|}
-Persona \\
Pertama Jamak
\end{tabular} & cita (kita) & bentuk bebas & $\begin{array}{l}\text {-menunjuk pada diri } \\
\text { pembicara dan mitra bicara }\end{array}$ \\
\hline (inklusif) & -ta (kita) & $\begin{array}{l}\text { bentuk terikat /lekat } \\
\text { kanan }\end{array}$ & $\begin{array}{l}\text { t-menyatakan milik } \\
\text { pembicara dan mitra bicara }\end{array}$ \\
\hline $\begin{array}{l}\text {-Persona Pertama } \\
\text { Jamak (eksklusif) }\end{array}$ & $\begin{array}{l}\text { cami (kami) } \\
\text { cami/camo (kami }\end{array}$ & $\begin{array}{l}\text { bentuk bebas } \\
\text { i bentuk bebas/ kanan }\end{array}$ & $\begin{array}{l}\text {-menunjuk pada diri pembicara } \\
\text { dan orang lain } \\
\text {-menyatakan milik } \\
\text { npembicara dan orang lain }\end{array}$ \\
\hline \begin{tabular}{|lr} 
B. & -Persona \\
Kedua Tunggal
\end{tabular} & $\begin{array}{l}\text { ko (engkau) } \\
\text {-nu (-mu) }\end{array}$ & $\begin{array}{l}\text { bentuk bebas } \\
\text { bentuk terikat /lekat } \\
\text { kanan }\end{array}$ & $\begin{array}{l}\text {-menunjuk pada mitra bicara sendiri } \\
\text {-menyatakan milik mitra bicara }\end{array}$ \\
\hline $\begin{array}{l}\text {-Persona Kedua } \\
\text { Jamak }\end{array}$ & $\begin{array}{l}\text { camo/kamo } \\
\text { /kamo pakasa } \\
\text { (kalian) } \\
\text {-iow (kalian) }\end{array}$ & $\begin{array}{l}\text { bentuk bebas/ frasa } \\
\text { bentuk terikat /lekat } \\
\text { kanan }\end{array}$ & $\begin{array}{l}\text {-menunjuk pada mitra bicara } \\
\text { dan orang lain } \\
\text { t-Menyatakan milik mitra bicara dan } \\
\text { orang lain }\end{array}$ \\
\hline $\begin{array}{lr}\text { C. } & \text {-Persona } \\
\text { Ketiga } & \text { Tunggal }\end{array}$ & -na (-nya) & $\begin{array}{l}\text { bentuk bebas } \\
\text { bentuk terikat /lekat } \\
\text { kanan }\end{array}$ & $\begin{array}{l}\text {-menunjuk pada } \\
\text { Seseorang yang dibicarakan (laki- laki } \\
\text { perempuan) } \\
\text { t-menyatakan milik dari yang dibicaraka } \\
\text { (laki- laki / perempuan) }\end{array}$ \\
\hline $\begin{array}{l}\text {-Persona Ketiga } \\
\text { Jamak }\end{array}$ & $\begin{array}{l}\text { seila/sela/sera } \\
\quad(\text { mereka }) \\
\text {-ela/-era/-nela } \\
\text { (mereka) }\end{array}$ & $\begin{array}{l}\text { bentuk bebas } \\
\text { bentuk terikat /lekat } \\
\text { kanan }\end{array}$ & $\begin{array}{l}\text {-menunjuk pada seseorang yang } \\
\text { dibicarakan dan orang lain } \\
\text {-menyatakn milik orang yang } \\
\text { tdibicarakan dan orang lain }\end{array}$ \\
\hline
\end{tabular}




\section{Deiksis Tempat/Ruang}

\begin{tabular}{|l|c|c|l|}
\hline Tempat/Ruang & Deiksis & \multicolumn{1}{|c|}{ Bentuk } & Fungsi Deiksis \\
\hline di sini & ambi? & bentuk bebas/kata & $\begin{array}{l}\text { Menunjuk tempat yang dekat dengan } \\
\text { pembicara }\end{array}$ \\
\hline di sana & asyanonge & bentuk bebas/kata & $\begin{array}{l}\text { menunjuk tempat yang jauh da } \\
\text { pembicara dan mitra bicara }\end{array}$ \\
\hline
\end{tabular}




\begin{tabular}{|c|c|c|c|}
\hline di situ & ambityu & bentuk bebas/kata & $\begin{array}{l}\text { Menunjuk tempat yang dekat denga } \\
\text { mitra bicara }\end{array}$ \\
\hline
\end{tabular}

\subsubsection{Deiksis Waktu}

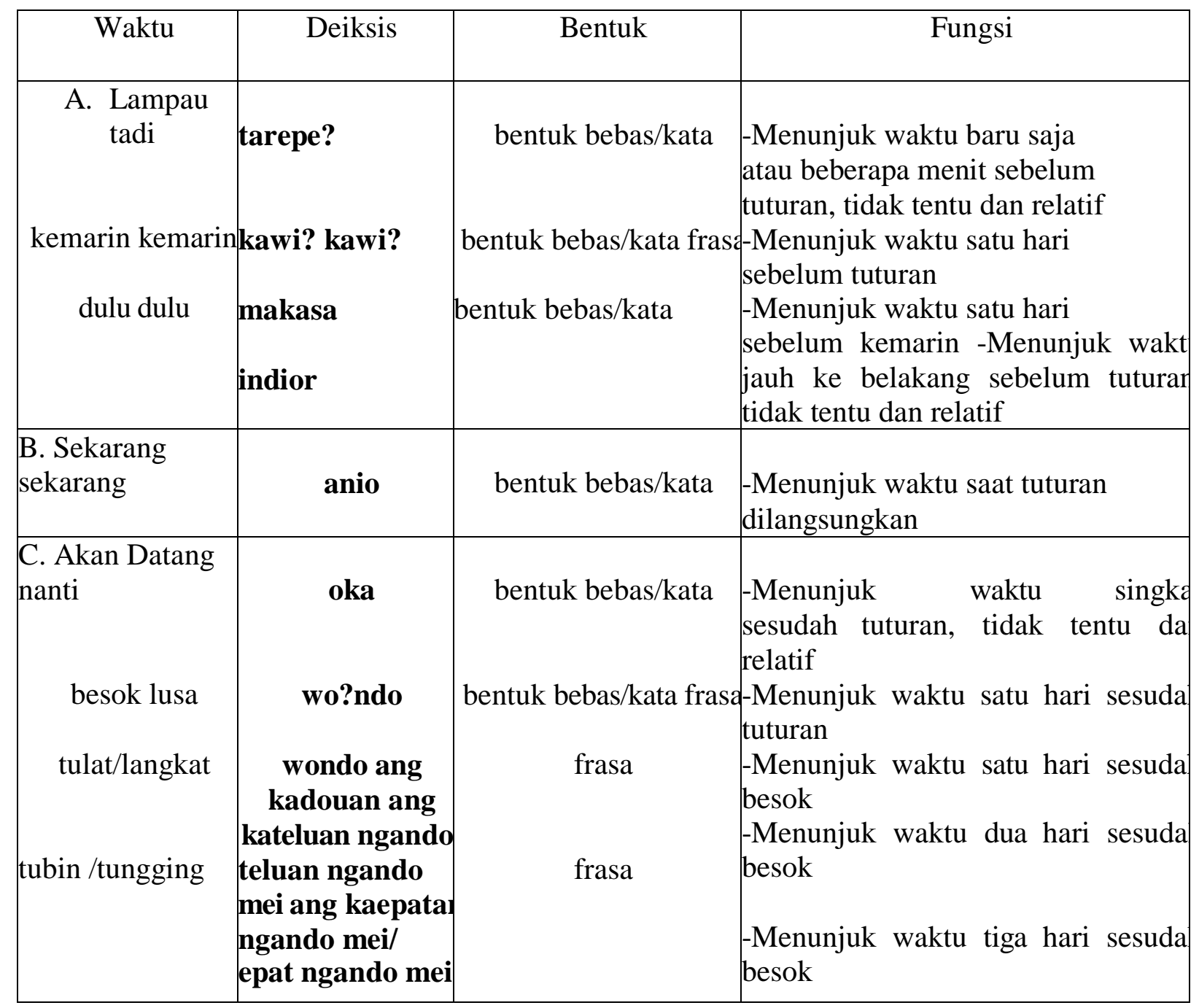

\section{Pembahasan}

\section{Deiksis Persona}

A. Deiksis Persona Pertama Tunggal

- $\boldsymbol{y a k u}$ 'saya' ; $-\boldsymbol{k u}$ '-ku'

Deiksis yaku 'saya' adalah bentuk yang berfungsi menggantikan diri si pembicara itu sendiri

Contoh :

1. Yaku nemema pedalan.

'Saya sudah membuat tinutuan' 


\section{Sinere na yaku ang pasar.}

'Dia melihat saya di pasar'

\section{Telen ange karai yaku!}

'Belikan saya pakaian!'

Bentuk yaku 'saya' adalah bentuk persona pertama tunggal (singular). Bentuk ini secara morfologis merupakan bentuk bebas karena dapat berdiri sendiri. Deiksis yaku 'saya' dapat digunakan oleh siapa saja baik orang tua, anak-anak, orang yang dihormati, maupun orang yang belum dikenal. Juga digunakan baik dalam situasi formal maupun informal, dan bersifat akrab. Bagi anak-anak yang masih terlalu kecil, penggunaan deiksis persona pertama tunggal masih merupakan hal yang membingungkan. Karena itu, mereka sering menggantikannya dengan nama diri, ketika hendak menyebut diri sendiri, misalnya :

4. Mama, Ewis mailek melep.

Mama, Ewis (yaku) minta minum'

Deiksis persona yaku 'saya' memiliki bentuk posesif $-\mathbf{k u}$ ' $-k u$ '. Bentuk ini merujuk pada seseorang yang merupakan pemilik yaitu si pembicara, dan secara morfemis deiksis $-k u$ ' $-\mathrm{ku}$ ' adalah bentuk terikat, yang lekat kanan. Contoh dalam kalimat :

5. Ca kaindoanera en sisiri?inku.

'Tidak ada yang bisa merebut kehormatanku'

6. Wukuku nirombit e tou.

'Bukuku di curi orang'

7. Pinelanu eng si tantaku?

'Apakah engkau melihat bibiku?'

B. Deiksis Persona Pertama Jamak

- cami 'kami', cami 'kami'

Deiksis cami 'kami' adalah kata ganti yang merujuk kepada pembicara dan orang lain (orang ketiga) yang tidak hadir ataupun hadir dalam kegiatan tutur, contoh

1. Cami wo maento ke ang talun.

'Dulu kami hanya tinggal di hutan.'

2. Wineanna karu cami wi?ir.

'Dia yang telah memberikan kami beras.'

3. Sa cami ca nimei, ca wana tou nimasembong ang pinestaan.

'Kalau kami tidak datang, maka tidak ada orang yang membantu di pesta itu.'

Bentuk cami 'kami' termasuk bentuk eksklusif, yaitu gabungan antara persona pertama dan ketiga atau persona pertama jamak. Bentuk atau deiksis cami 'kami' digunakan oleh siapa saja baik orang tua ataupun anak-anak, dalam situasi formal atau informal, maupun dalam suasana keakraban atau kekeluargaan. Deiksis cami 'kami' memiliki bentuk posesif cami 'kami'. Bentuk cami 'kami' termasuk sebagai bentuk bebas sebagaimana dalam bahasa Indonesia, karena termasuk rumpun yang sama yaitu rumpun Austronesia. Oleh karena itu, secara morfologis bentuk ini merupakan bentuk bebas, dan secara distribusi berada pada posisi bagian kanan. Sebagai contoh dapat dilihat pada kalimat-kalimat berikut :

4. Karay cami wilitenoka wondo angkadouan.

'Baju kami nanti akan dijahit lusa'

5. Inorasem nimento? em eng sisinoen cami.

'Pada waktu tengah hari pelajaran kami sudah berhenti'

6. Tas cami sei keli.

'Tas kami banyak'

- cita 'kita', -ta 'kita' 
Cita 'kita' termasuk kata ganti yang merujuk pada persona pertama dan persona kedua atau tepatnya merujuk pada pembicara dan mitra bicara, seperti contoh berikut:

7. Cita semerite pe?

'Kita bercerita dulu'

8. Soso'den ange po?po? cita! ‘

Tolong panjatkan kelapa untuk kita'

9. Cita maindope? po?po?

'Kita masih akan mengambil kelapa'

Deiksis cita 'kita' termasuk bentuk inklusif yaitu gabungan antara persona pertama dan persona kedua. Deiksis cita 'kita' adalah bentuk bebas secara morfologis. Bentuk ini digunakan oleh siapa saja baik orang tua, orang yang dihormati, teman sejawat, maupun anak-anak, baik dalam situasi formal atau informal, santai dan kekeluargaan. Deiksis cita 'kita' mempunyai bentuk yang menyatakan kepemilikan yaitu -ta 'kita'. Bentuk posesif dari cita 'kita' adalah bentuk terikat, berbeda halnya dengan bentuk posesif eksklusif cami 'kami' yang bersifat bebas. Secara distribusi bentuk posesif ini adalah lekat kanan. Contoh :

10. Awian nimaboy en umata.

'Ada yang bertanya ingin membeli kebun kita.'

11. Takura re pabangkeran eng tabeta?

'Harga berapa kebun sawah kita kalau dijual?'

12. Sei re? en si matawoi en umata?

'Siapa yang mengerjakan kebun kita?'

C. Deiksis Persona Kedua Tunggal

- ko 'engkau' -nu'-mu'

Bentuk ko 'engkau' termasuk bentuk bebas atau berupa kata, seperti pada contoh berikut ini :

1. Masekolah ambisa ko?

'Engkau sekolah di mana?'

2. Mabisa re' ko?

'Engkau mau ke mana, ya?'

3. Sa ko lumangkoy ang Kawangkoan, tumuli mio tumeles ragey

'Jika engkau lewat Kawangkoan, jangan lupa mampir beli ragey'

Kata ganti persona kedua tunggal ko 'engkau' merupakan kata ganti yang merujuk pada mitra bicara/ teman bicara. Kalimat-kalimat yang ada pada contoh kalimat nomor (20) sampai dengan nomor (22) tidak diketahui siapa yang menjadi mitra bicara. Bentuk ini sebenarnya tidak lazim digunakan terhadap orang yang lebih tua, orang yang belum dikenal, atau orang yang dihormati, karena dianggap kurang sopan. Bentuk ko 'engkau' lebih tepat digunakan terhadap orang yang lebih muda atau seusia. Digunakan dalam situasi informal dan akrab. Untuk berkomunikasi dengan orang yang lebih tua, orang yang dihormati, atau orang yang belum dikenal biasanya menggunakan bentuk sapaan (mama), atau nama jabatan (pandeta). Contoh :

4. Mabisa re' mama (ko)?

'Ibu mau ke mana, ya?'

5. Pendeta (ko) mimpin ibadah ambisa ko tarepe'

'Pendeta akan memimpin ibadah dimana sebentar malam?'

Bentuk yang menyatakan kepemilikan atau posesif persona kedua tunggal adalah $-n u$ '-mu'. Bentuk -nu'-mu seperti berikut :

6. Karainu keromos oka pakaseren.

'Bajumu kelihatannya sudah kotor'

7. Sia karu si masere-sere a si mamanu ang sinakitan.

'Dia yang selalu merawat Ibumu pada saat sakit.' 


\section{Ambisa tinelesannu eng karainu.}

'Dimana engkau membeli bajumu?'

D. Deiksis Persona Kedua Jamak

-camo /kamo/kamo pakasa 'kalian' ; -iow 'kalian'

Deiksis persona kedua jamak memiliki bentuk yang bervariasi, ditandai dengan bentuk camo/kamo/kamo pakasa 'kalian'. Ketiga bentuk ini dapat dipertukarkan. Deiksis ini berfungsi menggantikan teman bicara atau mitra bicara yang jumlahnya lebih dari satu orang, dan tidak melibatkan pembicara, contoh :

1. Sa kamo pakasa tumawoy, tumawoy ange sama? karu.

'Kalau kalian bekerja, bekerjalah dengan sungguh-sungguh'.

2. Kamo kwa makarenet_ke mawali-wali ang pabaya?an

'Kalian selalu bersama-sama di perjalanan.

3. Kawisa re camo mareng mei?

'Kapan kalian pulang kembali.'

Bentuk camo / kamo / kamo pakasa 'kalian' adalah bentuk bebas dan berupa frasa. Bentuk ini lazim digunakan terhadap mitra bicara yang setara /seusia atau lebih muda. Jarang digunakan terhadap orang-orang yang dihormati atau yang lebih tua karena dianggap kurang sopan, sehingga diganti dengan menggunakan bentuk sapaan atau nama jabatan, seperti

4. Se papasatu (camo/kamo) mawuri sawisa ti Jakarta.

'Paman-paman pulang kapan ke Jakarta'

5. Ambisa en tawoyan guru-guru wo?ndo?

'Dimana kamu akan bekerja besok?

Untuk menyatakan posesif orang kedua jamak camo /kamo/ kamo pakasa 'kalian' digunakan bentuk terikat -iow 'kalian' seperti

6. Ambisa sia tineles eng karayiow?

'Dimana dia membeli baju kalian'

7. Yaku nimasere-sere eng waleiow indior.

'Saya yang menjaga rumah kalian waktu dulu'

8. Kawayoiow repet terang matincas.

'Kuda kalian sangat cepat berlari.'

Bentuk -iow 'kalian' sebagai posesif dikategorikan sebagai bentuk terikat dari segi morfologis karena tidak dapat diucapkan tersendiri. Letaknya di bagian kanan secara distribusi.

E. Deiksis Persona Ketiga Tunggal

- sia 'dia'; -na '-nya'

Deiksis sia 'dia' berfungsi menggantikan persona ketiga tunggal, yang merujuk pada seseorang tidak dikenal/diketahui, contoh

1. Nimange ang benang sia?

'Dia sedang pergi ke Manado?'

2. Sia karu nimasere-sere a si mamaela ang sakitan.

'Dia yang menjaga mama mereka ketika sakit'

3. Sa sia marengei, wia en nange kupang sia.

'Kalau dia pulang, tolong berikan dia uang'

Bentuk sia 'dia' pada kalimat nomor 36, 37 dan 38 merupakan deiksis persona yang berwujud sebagai kata atau bentuk bebas. Sia 'dia' berfungsi menggantikan seseorang baik perempuan ataupun pria, yang sedang dibicarakan yang mungkin saja tidak hadir atau hadir tetapi tidak terlibat dalam kegiatan tutur. Deiksis sia 'dia' digunakan terhadap siapa saja, baik terhadap orang yang lebih tua atau lebih muda, dalam situasi formal atau informal, bersifat akrab dan kekeluargaan. Bentuk posesif dari deiksis sia 'dia' adalah -na'-nya'. Bentuk ini 
termasuk bentuk terikat lekat kanan, tidak berdiri sendiri. Bentuk ini menyatakan kepemilikan persona ketiga tunggal, seperti

4. Paleo-leosanna karu ya si tuarina.

'Dia selalu memperlakukan adiknya dengan penuh kasih sayang.'

5. Si walena yana, pakatelesanna pe.

'Rumahnya itu baru saja dibeli olehnya.'

6. Tuarina mengaro-ngarot ingambarna'

'Adiknya mencoret-coret gambarnya'

F. Deiksis Persona Ketiga Jamak

- sera/sela/ seila 'mereka' ; -ela /-era/-nela 'mereka'

Deiksis sera/sela/ seila 'mereka' adalah kata ganti bentuk plural, yang merujuk pada orangorang yang sedang dibicarakan, contoh

1. Sera mato?tolo makan.

'Mereka sudah mulai makan'

2. Sela karu maento ke ang numa indior.

'Kasihan dahulu mereka tinggal di kebun'

3. Seila minggu mei kawengan.

'Minggu depan mereka ada perkawinan'

Deiksis sera 'mereka' memiliki variasi bebas yaitu sera/sela/seila 'mereka' yang dapat saling dipertukarkan. Hal ini disebabkan daerah pengguna bahasa Tontemboan terbagi atas daerah matana'i dan daerah makela'i. Di daerah Makela'i digunakan bentuk seila dan di daerah Matana'i digunakan bentuk sera /sela. Dengan perkembangan jaman kedua bentuk ini sering digunakan oleh kedua wilayah, yaitu Makela'i dan Matana'i. Bentuk ini merupakan bentuk bebas. Deiksis sera 'mereka'memiliki bentuk posesif yaitu menyatakan kepemilikan dan digunakan bentuk terikat lekat kanan, yaitu - eral -ela. Sebagai contoh dapat dilihat pada kalimat-kalimat berikut :

4. Kinalentuaan kiki karu si kawayoela.

'Kuda mereka kakinya sudah patah.'

5. Copusen tantu ela si tuariera.

'Mereka sangat sayang kepada adik mereka'

6. Papaarenera makakawuse?

'Pembicaraan mereka baru berakhir'

Deksis Tempat/Ruang

Deiksis tempat/ruang merupakan kata ganti yang merujuk pada suatu tempat yang sedang dibicarakan. Deiksis ini menunjuk tempat yang belum diketahui. Dalam bahasa Tontemboan ditemukan beberapa deiksis seperti berikut ini

- ambi?' di sini'

Deiksis ambi? 'di sini' adalah bentuk bebas, yang berfungsi menggantikan tempat yang berada di dekat pembicara, seperti pada contoh-contoh berikut :

1. Catoro semamek ambi?!

'Dilarang buang air kecil di sini!'

2. Kawi? i ambi? awian tou marombit.

'Kemarin di sini ada orang yang mencuri.'

3. Ambi? karu cawana se palingan nei se toya? ang ma keret ang lalan.

'Kalau di sini tidak terdengar ada anak-anak yang berteriak di jalan'

-asyanonge 'di sana' 
Bentuk asyanonge 'di sana' termasuk bentuk bebas. Deiksis ini berfungsi merujuk pada suatu tempat yang letaknya jauh dari si pembicara. Sebagai contoh dapat dilihat pada kalimat-kalimat berikut :

4. Asyianonge paentoan e mahasiswa KKN.

'Di sana tempat tinggal mahasiswa KKN'

5. Asyianonge eng paemaan wale weru kayu.

'Di sana tempat pembuatan rumah baru dari kayu'

6. Asyianonge eng paserean ni patincasan/patintasan kawayo'

'Di sana tempat perlombaan kuda pacu (pacuan kuda)'

- ambitu 'di situ'

Deiksis ambitu 'di situ' adalah bentuk bebas. Deiksis ini menggantikan tempat yang menunjuk ke arah yang jauh dari pembicara atau penutur tetapi berada di dekat teman bicara atau petutur. Contohnya :

7. Ambitu sinereku eng towakunu.

'Saya lihat rokokmu di situ.'

8. Lumuketem ambitu ko!

'Kamu duduk saja di situ!'

9. Pinelanu ambitu eng sapatu ku?

'Apakah kamu melihat sepatuku di situ?'

Deiksis Waktu

Deiksis waktu menunjuk pada waktu berlangsungnya sebuah peristiwa, baik kala lampau, kala kini, maupun kala mendatang.

a. Waktu Lampau

- tarepe? 'tadi

Tarepe' 'tadi' adalah deiksis yang menyatakan waktu lampau. Kata atau deiksis tarepe' 'tadi' bertitik labuh pada saat sebelum tuturan, tetapi tidak terlalu lama. Bisa saja baru 1 menit yang lalu. Tarepe? 'tadi' termasuk bentuk bebas, tidak tentu dan relatif.

Contoh :

1. Sia tarepe? tumelepon.

'Tadi dia menelpon'

2. Sela tarepe? mange ang Sonder.

'Tadi mereka pergi ke Sonder'

3. Cami terepe? matanaem mange ambitu.

'Tadi kami berencana pergi ke situ'

-kawi? 'kemarin'

Deiksis kawi? 'kemarin' adalah kata ganti yang berfungsi menyatakan waktu, yang bertitik labuh pada satu hari sebelum saat tuturan. Secara morfologis deiksis ini termasuk bentuk bebas. Contoh :

4. Ka'wi? muran repet ambi.

'Kemarin hujan keras di sini'

5. Kawi? sia ni mareng mei.

'Kemarin dia pulang.'

6. Pinesungkulku sia kawi? ang Benang.

'Saya bertemu dia kemarin di Manado.'

-kawi? makasa 'kemarin dulu' 
Kawi? makasa 'kemarin dulu' adalah deiksis yang berupa frasa. Bentuk ini berfungsi menyatakan waktu yang bertitik labuh pada satu hari sebelum kemarin.

Contoh :

7. Kawi? makasa nimamuali tanah goyang an ambi.

'Kemarin dulu di sini terjadi gempa.'

8. Kawi? makasa sia matanaem wo' semengkotem.

'Kemarin dulu dia sudah merencanakan untuk berlayar.'

9. Pinesungkul ku sela kawi? makasa ang Amurang.

'Saya bertemu mereka kemarin dulu di Amurang'

- indior 'dahulu'

Bentuk indior 'dahulu' termasuk leksem tidak tertentu dan relatif. Bentuk ini adalah kata ganti yang menyatakan waktu sebelum tuturan dan menunjuk waktu yang jauh ke belakang,contoh :

10. Indior se tou ambii ma?kan tutu? tandey

'Dahulu orang-orang disini makan nasi jagung'

11. Yaku indior masekolah ang Langoan'

'Saya dahulu sekolah di Langowan'

12. Indior sela mawangker ang pasar Kawangkoan.

'Dahulu mereka berjualan di pasar Kawangkoan'

b.Waktu Sekarang

- anio 'sekarang'

Deiksis anio 'sekarang' adalah bentuk bebas secara morfologis. anio 'sekarang' merujuk pada saat penutur berbicara atau bertitik labuh pada saat tuturan berlangsung.

Contoh :

13. Mangem kamo a si endo anio?

'Apakah kalian akan pergi sekarang?

14. A si jam anio?ma'yam cami ang papesungkulan.

'Sekarang kita akan pergi ke tempat pertemuan.'

15. A si wo?ndo anio? tumu'dem se masu'up wene'

'Sekarang para pekerja akan memulai memotong padi.'

Dari contoh-contoh di atas memperlihatkan bahwa dalam penggunaan deiksis anio 'sekarang' Terdapat bentuk lain yang berfungsi mempertegas, seperti bentuk endo 'hari' dalam endo anio 'sekarang ini', jam 'jam/waktu' dalam jam anio 'jam ini', wo?ndo 'pagi' dalam wo?ndo anio 'sekarang ini/pagi ini.

c. Waktu Akan Datang

- oka'nanti

Bentuk oka 'nanti' adalah bentuk bebas yang menyatakan waktu akan datang, seperti pada

kalimat-kalimat berikut :

15. Masungkul oka ke? ey.

'Sampai jumpa nanti'

16. Tumuli oka re?maisa sa marengomei.

'Nanti saja kembali baru mampir'

17. Karayku wiliten oka wo'ondo'

'Bajuku nanti akan dijahit besok'

Pada contoh kalimat di atas, bentuk oka 'nanti' berfungsi merujuk pada waktu sesudah tuturan, tetapi hanya beberapa saat. Dapat saja waktunya hanya 1 menit sesudah tuturan. 
- wo?ndo 'besok'

Deiksis wo?ndo 'besok' adalah leksem waktu yang berfungsi menyatakan waktu satu hari sesudah saat tuturan atau bertitik labuh pada satu hari sesudah peristiwa tutur. Deiksis ini termasuk bentuk bebas secara morfologis.

Contoh :

18. Wo?ndo oka tare cita mesungkul an uma.

'Nanti besok kita bertemu di kebun.'

19. Sa wo ro?na, mei ange ko wo?ndo ambale?

'Kalau boleh, besok kamu datang ke rumah.'

20. Wo?ndo oka yaku mange mei tumeles karai.

'Nanti besok saya akan pergi membeli pakaian.'

- Wo?ndo ang kandouan 'lusa'

Bentuk wondo angkandouan 'lusa' berupa frasa, yang berfungsi menyatakan waktu.

Wondo angkandouan 'lusa' bertitik labuh pada satu hari sesudah besok. Contoh :

21. Wo?ndo ang kandouan awian rorokan a ro'ongta.

'Lusa ada kunjangan di desa kita.'

22. Matanei ke mange wo?ndo ang kandouan awian ke pinistaan ang kasuputa.

'Mengingat bahwa lusa ada acara pesta lagi di tetangga kita.'

23. Wo?ndo ang kaendoan a wean umungan.

'Lusa ada rapat'

- $\quad$ Ang kateluan ngando 'tulat (langkat)'

Deiksis ang kateluan ngando 'tulat' berfungsi menggantikan waktu, yaitu bertitik labuh pada dua hari sesudah besok. Bentuk ini berupa frasa.

Contoh :

24. Ang kateluan ngando yaku muse?bem tande.

'Tulat saya akan menanam jagung'

25. Ang kateluan ngando awian pemilihan kepala desa anambi.

'Tulat akan ada pemilihan kepala desa.'

26. Sela mange am benang ang kateluan ngando.

'Tulat mereka akan pergi ke Manado'

- $\quad$ Ang kaepat ngando mei 'tubin (tungging)'

Bentuk ang kaepat ngando mei 'tubin (tungging)' berbentuk frasa. Bentuk ini bertitik labuh pada tiga hari sesudah saat tuturan. Berikut contoh-contohnya :

27. Ang kaepat ngando mei si endo demingu.

'Tubin sudah hari minggu'

28. Ang kaepat ngando mei cawana se mawangker ang pasar lantaran si Corona yana.

'Tubin sudah tidak ada lagi yang berjualan di pasar karena ada penyakit Corona.'

29. Sela mange am benang angkaepat ngando mei.

'Tubin mereka akan pergi ke Manado'

\section{Kesimpulan}

Dalam analisis bentuk dan fungsi deiksis bahasa Tontemboan ditemukan bahwa bentuk deiksis bervariasi, ada yang berupa morfem terikat, kata, dan frasa. Yang berbentuk morfem terlihat pada penanda posesif yang hampir semuanya terikat, kecuali penanda orang kedua jamak (camo/kamo 'kalian') sebagaimana dalam bahasa Indonesia. Yang berbentuk frasa nampak pada deiksis yang menyatakan waktu, lebih khusus waktu lampau (kawi? makasa 'kemarin 
dulu') dan waktu akan datang (wo?ndo ang kadouan 'lusa', ang kateluan ngando 'tulat', ang kaepatan ngando 'tubin'). Penamaan waktu lampau ditandai dengan penyebutan bilangan, seperti dou 'dua', telu 'tiga', epat 'empat' maksudnya dihitung dari titik nol. Beberapa bentuk deiksis memiliki variasi bebas, seperti pada penanda waktu akan datang ang kateluan ngando/teluan ngando mei 'tulat' dan ang kaepatan ngando mei/ epat ngando mei 'tubin' dan penanda personal pronomen ketiga jamak sera/sela/seila 'mereka', yeng mana bentuk-bentuk itu dapat dipertukarkan. Kecuali bentuk sera/sela/seila 'mereka' disinyalir penutur yang berada di wilayah makela?i menggunakan kata seila 'mereka'. Seiring dengan perkembangan jaman maka baik yang berada di wilayah makela?i maupun matana?i sudah menggunakan seila'mereka'. Dalam bahasa Tontemboan mengenal bentuk eksklusif cami 'kami' dan inklusif cita 'kita'. Untuk menentukan fungsi deiksis dapat ditelusuri mengikuti jenis deiksisnya. Dalam hal penunjukan tempat/ruang ditemui memiliki 3 pembedaan yaitu, ambi? di sini', asyanonge 'di sana' dan ambitu 'di situ'. Dari perolehan bentuk-bentuk deiksis tergambar bahwa bahasa Tontemboan memiliki banyak penanda deiksis. Hipotesis Frei mengatakan bahwa semakin tinggi tingkat kebudayaan, maka seharusnya semakin sederhana sistem deiktis bahasa bersangkutan, dalam arti bahasa tersebut tidak memerlukan deiksis yang banyak dan rumit.

\section{Daftar Pustaka}

Danie, J.A. 1991. Kajian Geografi Dialek Minahasa Timur Laut. Jakarta: Balai Pustaka. Djajasudarma, F.T. 1993. Metode Linguistik. Ancangan Metode dan Kajian. PT. Eresco Bandung.

Purwo, K. B. 1984. Deiksis Dalam Bahasa Indonesia. Jakarta : PN Balai Pustaka. Purwo, K. B. 1984. Pragmatik Dan Pengajaran Bahasa. Kanisius.

Leech, G. 1983. Principles of Pragmatics. Oxford University Press. Levinson, S. 1983. Pragmatics. England : Cambridge University Press. Lyons, J. 1977. Semantics 2. Cambridge : Cambridge University Press.

Nababan, P.W.J. 1984. Sosiolinguistik : Suatu Pengantar. Jakarta : PT. Gramedia. Nadar, F.X 2008. Pragmatik dan penelitian Pragmatik.Yogyakarta : Graha Ilmu Putrayasa, Ida Bagus. 2014. Pragmatik. Yogyakarta: Graha Ilmu.

Salea-Warouw, dkk. 1979/1980. Kamus Tombulu-Indonesia. Manado: Proyek Peningkatan/Pengembangan Perguruan Tinggi Universitas Sam Ratulangi.

Tallei, 1989. Pragmatik. Sebagai salah satu Alternatif Pendekatan Dalam Pengajaran Bahasa (Indonesia). Manado : CV Cahaya Patra.

Tarigan, H.G. 1986. Pengajaran Pragmatik. Bandung: Angkasa Yule, G. 2014. Pragmatik. Yogyakarta : Pustaka Pelajar 